\title{
Underviserens roller fra centrum til periferi
}

\author{
- eksempler på anvendelse af IT i sprogfagene
}

\author{
Hanne Leth Andersen \\ Lektor, ph.d. \\ Center for Undervisningsudvikling, Det Humanistiske og Det \\ Teologiske Fakultet \\ Aarhus Universitet \\ cfuhla@hum.au.dk \\ www.hum.au.dk/cfu
}

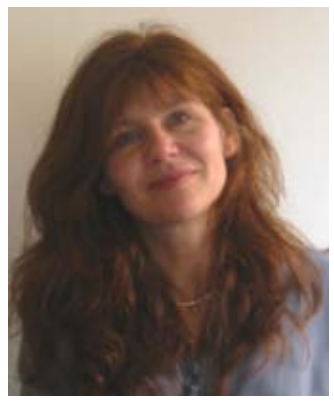

Baggrunden for Hanne Leth Andersens sprogpcedagogiske interesse ligger i knap 20 års undervisning primcert i fransk som fremmedsprog med fokus på sprogferdighed, overscettelse, grammatik og med et voksende fokus på sprogtilegnelsesforskning og sprogdidaktik. I artiklen interesserer hun sig for underviserrollen og de muligheder, inddragelse af IT i sprogundervisningen giver både for udvikling af sproglig viden og sproglig ferdighed. Hanne Leth Andersens artikel udkommer også som kapitel i Mathiasen, Helle (2006): Lcering og IT - kompetenceudvikling på de videregående uddannelser, Aarhus Universitetsforlag.

\section{Indledning}

Ikke mindst i sprogundervisningen er det væsentligt at komme bort fra en stærkt lærercentreret undervisning, idet der er behov for, at alle sproglærende får lejlighed til at anvende sproget i undervisningssituationen. Her er der derfor god brug for at arbejde med forskellige læringsrum og træningsrum, sådan som IT kan bidrage til. Samtidig følges eleverne ikke ad i deres udvikling af sproglige færdigheder, idet progressionen her ikke kan siges at være lineær og vidensbaseret, og det er derfor særligt vigtigt at kunne arbejde med en vis grad af undervisningsdifferentiering.

Udgangspunktet for denne artikel er følgende spørgsmål:

- Hvilke roller har fremtidens (sprog)underviser i det moderne læringsmiljø?

- Hvilken rolle spiller sprogsyn og læringssyn på anvendelsen af IT i sprogfagene?

- Kan IT anvendes udbytterigt i forbindelse med udvikling af sprogfærdighed og sproglig bevidsthed?

- Hvordan kan man udvikle mundtlig sprogkompetence skriftligt?

- Hvilken rolle spiller undervisningsdifferentiering?

Sprogfagene har særlige muligheder, når det drejer sig om inddragelse af IT eller digitale medier i undervisningen, fordi teknologiens tilbud inden for informationssøgning, videndeling, kommunikation og interaktion lægger op til og støtter færdighedstræning 
både i forhold til sproglig kompetence i form af mundtlig og skriftlig udtryksfærdighed på fremmedsproget samt udvikling af grammatisk viden og kunnen.

Udgangspunktet i dette kapitel er en gennemgang af de mange nye muligheder inden for arbejdet med sprogfærdighed som de IT $^{1}$-baserede læringsmiljøer tilbyder i forskellige konkrete læringssituationer. Det drejer sig om, med forskellige kompetencemål for øje, at facilitere sprogtilegnelse i form af udvikling af mundtlig og skriftlig udtryksfærdighed og forståelse samt sproglig viden. Lærerrollen bringes i fokus fordi den udvikler sig inden for disse rammer, hvor et klart mål ud over det rent faglige er at fremme de studerendes selvstændighed i tilegnelsesprocessen og udbygge deres evne til at reflektere såvel over sproget som over deres egen læring. Den tilgang til læring, som næsten naturligt ligger i den IT-baserede sprogundervisning, er konstruktivistisk og kompetenceorienteret, og den placerer den lærende centralt, mens læreren indtager rollen som konsulent og træner snarere end som skulptør (jf. Beck \& Gottlieb 2002) eller instruktør. Hvor underviserens rolle traditionelt oftest har været at videregive sin viden og instruktioner til elever eller studerende, som en instruktør der kender stykket eller en kunstner der arbejder sig frem mod et mere eller mindre bevidst mål, arbejder han i konsulent- eller trænerrollen snarere ud fra de lærendes egne projekter og målsætninger. Underviserens rolle bliver således umiddelbart mere perifer, mens den studerende indtager centrum i forhold til egne læreprocesser. Det er vigtigt at gøre sig klart, om disse roller rent faktisk er tæt på børn og unges læringsstil og generelle studieadfærd i dag, samt at undersøge i hvor høj grad IT-inddragelsen skal styres. Dette er naturligvis en meget væsentlig problemstilling i forhold til undervisningsudviklingen i fremtidens videregående uddannelser, og netop de måder sprogfagene anvender IT, belyser såvel de frie som de mere styrede anvendelser.

Udgangspunktet for IT-anvendelsen i sprogundervisningen må være ikke at assimilere teknologien til en konventionel sprogundervisning med risiko for at genindføre forældede metoder, som sprogtilegnelsesforskningen for længst har forkastet, men at udvide sprogundervisningens muligheder ved at arbejde med moderne kommunikation og med inddragelse af tilgængelig viden om sprog og kultur via de nye medier.

I det følgende vil jeg først se på, hvordan anvendelsen af IT som didaktisk læremiddel både kan medvirke til en udvidelse af mulighederne i sprogundervisningen og samtidig kan fungere som en overførsel af arbejdsformer fra et medie til et andet uden nogen særlige ændringer. Det er således mere afgørende hvilket sprog- og læringssyn, der ligger til grund for undervisningen, end hvorvidt der anvendes IT, fordi det grundlæggende sprog- og læringssyn afgør, hvilke anvendelser af IT, der vælges. Således konkluderer den første evalueringsrapport fra det virtuelle gymnasium (UVM 2002, Status og perspektiver) da også, at "IT anvendes primært som redskab til at understøtte de undervisningsformer, som den enkelte lærer foretrækker”. Grundlæggende vil jeg i det følgende skelne mellem et behavioristisk-instruktivistisk læringssyn og et konstruktivistisk læringssyn. Herudover skal der, når det gælder sprogtilegnelse, skelnes mellem viden om sprog og sprogfærdighed. Man har traditionelt i den grammatikbaserede sprogundervisning antaget, at viden om sproglig form og struktur automatisk kan overføres til sproglige færdigheder. Dette synspunkt er blevet kraftigt nuanceret af moderne sprogtilegnelsesforskning. 
Dernæst præsenteres en række konkrete erfaringer fra udvalgte anvendelser af IT i undervisningen, nemlig forskellige former for anvendelse af internettet, herunder chat, arbejdet med den mundtlige dialog i en IT-sammenhæng, og endelig anvendelsen af korpora (tekstsamlinger) og konkordanser (ordsøgningsprogrammer der søger på enkeltord, orddele eller sammensætninger af ord, med et nærmere defineret stykke omgivende tekst). Undervisningseksemplerne er hentet fra såvel universitet som gymnasium og det er synspunktet, at de forskellige anvendelser uden problemer kan overføres til andre niveauer og andre sprogfag end der, hvor de er udviklet.

Det teoretiske fundament for gennemgang og analyse er hentet fra den lingvistiske forskning, herunder konversationsanalysen, sprogtilegnelsesforskningen, kommunikationsforskning og pædagogiske teorier, herunder omkring læringsmiljøer og lærerroller, samt fremmedsprogspædagogik.

\section{IT, sprogsyn og læringssyn}

Når man inddrager IT i sprogundervisningen, sker det naturligt nok inden for rammerne af det sprogsyn og det læringssyn, der ligger i det enkelte sprogfag og hos den enkelte underviser. Det er ofte blevet understreget, at sprogfagene på disse områder bestemt ikke er homogene (jf. Andersen 2005b). På tværs af de mange forskellige tilgange som findes inden for fremmedsprogsfagene på de forskellige forsknings- og uddannelsesinstitutioner, kan man grundlæggende identificere to paradigmer, to måder at anskue sprog på (sprogsyn) i sprogfagene, nemlig det strukturalistiske, som anskuer sprog som struktur og system (fx Saussure, Chomsky, Hjelmslev), og det kommunikative (fx Byram, Risager, Kramsch), som anskuer sprog primært som et kommunikationsmiddel mellem mennesker og kulturer. Man kan sige at den strukturalistiske tilgang fokuserer på sætninger og deres opbygning, mens det kommunikative fokuserer på sprogbrugen.

Tilsvarende finder vi i sprogfagene de to grundlæggende læringssyn eller tilgange til undervisningssituationen, som genfindes i de fleste andre fag, nemlig det behavioristiskinstruktivistiske og det konstruktivistiske. Det behavioristiske læringssyn har spillet en meget væsentlig rolle i sprogundervisningen, og gør det stadig. Netop når det gælder træning af sprogfærdighed, er det oplagt at træne 'gode vaner' og at arbejde på at gentage korrekte sætninger, indtil disse 'sidder fast'. Dette kan stadig hævdes at være fornuftigt nok, men samtidig har det behavioristiske tilegnelsessyn betydet, at lærere og elever har været unødigt fejlforskrækkede og antaget, at fejl var både vanedannende og smitsomme. Dette er siden blevet kraftigt dementeret af den sprogtilegnelsesforskning, der tager sit udgangspunkt i en antagelse om, at den sproglærende har et sprog, det såkaldte intersprog, som hele tiden er under udvikling ${ }^{2}$. For at dette sprog kan udvikle sig, danner og afprøver den sproglærende hypoteser, hvilket afføder fejl. Disse fejl er således tegn på udvikling og ikke på vanedannelse. Man kan placere intersprogsforskningen inden for det konstruktivistiske læringssyn, hvor udgangspunktet netop er, at den lærende konstruerer den nye viden eller færdighed på sit eget fundament af viden eller færdighed.

Hverken de to sprogsyn eller de to læringssyn udelukker hinanden, men de forskellige tilgange kan være mere eller mindre orienterede mod den ene eller den anden pol og 
derved blive grundlæggende forskellige, og de danner udgangspunktet for, hvordan man betragter computerens, den lærendes og underviserens rolle i forbindelse med integrationen af den nye teknologi samt for de typer af øvelser og opgaver, der stilles i undervisningen, når de nye medier inddrages.

Computeren stiller mange muligheder til rådighed for den sproglærende: grammatikprogrammer, glosetræningsprogrammer, åbne og lukkede opgavetyper, tekstkorpora, film, musik og meget andet.

Er udgangspunktet for undervisningen et strukturalistisk sprogsyn og et behavioristiskinstruktivistisk videns- og læringssyn, anvendes typisk lukkede grammatiske opgaver som udfyldningsøvelser, lukkede spørgsmål/svar-aktiviteter og multiple choice, hvor computeren kan tjekke løsningen af opgaverne og give svar af typen "rigtigt"/'forkert". Computeren overtager på denne måde den instruktive lærerrolle og strukturerer og kontrollerer læringsprocessen, med den konsekvens, at den lærendes egen rolle som selvstændigt vælgende i processen nedtones.

Sprogtilegnelsen deles i sådanne øvelser op i forskellige trin, der hver især fokuserer på én bestemt færdighed, der menes at kunne læres uafhængigt af andre færdigheder. Den sproglige progression opfattes som byggesten og defineres udelukkende som en trinvis opbygning af konkret grammatisk viden, som først skal indøves for derefter automatisk at kunne anvendes i mundtlig og skriftlig sprogproduktion. Eksempler på en sådan anvendelse af computeren i sprogundervisningen findes først og fremmest på en lang række cd-rom'er ofte i forbindelse med begyndersystemer, men også i mange øvelsessamlinger der er tilgængelige på internettet. Disse øvelser henvender sig til den enkelte individuelle lærende og giver derfor fin mulighed for undervisningsdifferentiering, men der lægges ikke op til nogen form for sproglig interaktion eller dialogisk eller kollaborativt arbejde i denne type øvelser.

Disse øvelser er som oftest indsætningsøvelser som grundlæggende er udviklet med udgangspunkt i et behavioristisk-instruktivistisk tilegnelsessyn og strukturalistisk sprogsyn. De kan være nyttige, når en elev har fokus på et sprogligt problem, og behandlingen af det passer ind i elevens tilegnelsesrækkefølge, således at øvelsen ikke blot bliver en logisk-systematisk foreteelse, men rent faktisk får indflydelse på udviklingen af elevens intersprog. Hvis dette ikke er tilfældet, er sådanne øvelser ofte uden noget særligt udbytte, bortset fra at de kan give den enkelte indtryk af at have gennemført en sproglig aktivitet. Eleverne oplever da også ofte at disse øvelsestyper ikke er særligt anvendelige, hvilket Krøjgaard og Grydehøj (2001) giver eksempler på ud fra en spørgeskemaundersøgelse besvaret af 71 fransk- og tyskelever. De elever, der fortrinsvis har brugt computeren til tekstbehandling og grammatikøvelser, kritiserer computeren for dens begrænsede anvendelsesværdi. De angiver at computeren er "utrolig gammeldags og ikke særlig pædagogisk opbygget [... man kan] blot øve og terpe gloser og verber på en computer” eller "det er ofte lidt for løst at bruge pc, man skriver et forkert svar tre gange, og så kommer computeren med svaret og man går videre uden at tænke mere over fejlen”. 
Andre elever i andre situationer kunne naturligvis finde denne type øvelser meget tilfredsstillende, idet det kan være tilfredsstillende at have gennemført en øvelse vedrørende et bestemt grammatisk emne og dermed have en fornemmelse af at have tilegnet sig dette. Når sprogelever frustreres over forkert svar, kan dette også hænge sammen med, at mange programmer ikke har været i stand til at frasortere mindre væsentlige stavefejl i forhold til forkert anvendelse af ord og udtryk og dermed ikke adskille strukturfejl, udviklingsfejl og kommunikationsfejl. Dette er naturligvis et meget vanskeligt område, men det er vigtigt både for sproglærere og for computere at differentiere de forskellige fejltyper, for at eleven kan få en progression, der svarer til vores viden om de kognitive sprogtilegnelsesprocesser.

Computeren lægger herudover klart op til andre, mere åbne opgavetyper end de grammatiske øvelser med fokus på den korrekte sproglige form, og med kun et enkelt muligt svar. I task-baserede øvelser, både lukkede og åbne, er den lærende en aktiv deltager, og der fokuseres ikke specifikt på udviklingen af én enkelt færdighed. Til gengæld er den lærende nødt til at kunne inddrage flere sproglige færdigheder i et mere komplekst samspil, som kommer tættere på en autentisk kommunikationssituation. Opgavetyperne har til formål at stimulere den lærendes egen konstruktion af viden eller færdighed og samtidig have et eksplicit mål, hvilket ligger i forlængelse af Piagets krav til undervisningsaktiviteter. Den task-baserede tilgang til sprogundervisningen er både med og uden computer en mere motiverende og autentisk tilgang til sproglæring, og den har et åbenlyst potentiale i forhold til at anvende internettet. En task defineres således af Willis (1996, s.36):

"a goal-oriented communicative activity with a specific outcome, where the emphasis is on exchanging meanings, not producing specific language forms"

Svendsen Pedersen (2001) nævner blandt de task-baserede opgaver: puslespil, problemløsning, informationskløft, beslutningstagning og meningsudveksling. Den taskbaserede tilgang lægger op til en interaktiv forhandlingsproces, hvor kommunikationen foregår i en kontekst.

Der er ingen tvivl om, at IT kan være et stærkt redskab til at skabe et aktivt og motiverende læringsmiljø i sprogfagene. Det er imidlertid oplagt, at den konventionelle udnyttelse af IT, hvor mediet blot er en maskinel variation i forhold til andre medier uden nogen særlige pædagogiske eller didaktiske konsekvenser, ikke er det centrale. Det interessante er, om IT inddrages som et nyt medie, der hjælper den sproglærende til at opdage nye sammenhænge og konstruere ny viden.

Selve IT-anvendelsen kan for mange elever i dag være stærkt motiverende, ikke mindst fordi det kan medvirke til at skabe autentiske interaktive kommunikationssituationer mellem elever både inden for klasserummet og med andre elever uden for dette. Allerede i den tidlige Freinet-skole anvendtes skreven kommunikation som vidensudveksling blandt eleverne, hvilket ses fremhævet af Warschauer (1997), som samtidig fremsætter den antagelse at autentisk kommunikation som kilde til kollaborativ læring i kraft af sit udgangspunkt i den enkeltes virkelighed trænger dybere ind og rodfæstes ligeledes 
dybere. Det er netop det centrale for Vygotsky (1978), at den sociale læring skaber rum for udvikling ved hjælp af såvel læreren som de øvrige deltagere/elever (more capable peers). En elev eller studerende kan således klare opgaver sammen med andre, som han eller hun ikke ville kunne klare alene:

"the distance between the actual development level as determined by independent problem solving and the level of potential development as determined through problem solving under adult guidance or in collaboration with more capable peers" (Vygotsky, 1978).

Jeg vil i det følgende tage udgangspunkt i nogle undervisningsmuligheder, der bygger på konstruktivistiske læringsprincipper og på kommunikative metoder.

\section{Internettet i sprogtræningen}

Internettet er en uudtømmelig kilde, som dækker utroligt mange funktioner, der kan være relevante i sprogundervisningen fra den tidlige begynderundervisning til det højeste niveau. Dertil kommer at danske børn og unge er vant til at anvende internettet. Blandt de 13-15-årige bruger 56 \% internettet dagligt. De bruger det i højere grad i fritiden end i skolen, til et bredt spektrum af aktiviteter såsom at høre eller downloade musik, tekst og billeder, spille spil, surfe, søge informationer og kommunikere via e-mail og chat (Bille et al. 2005). Det er derfor oplagt at bruge dette medie i undervisningssammenhæng i almindelighed, og i sprogundervisning i særdeleshed, fordi nettet anvender tekster på mange sprog, det indeholder information om sprog og kulturer, samfund, offentlige og private institutioner, underholdning, dagligliv og privatliv, og det giver et utal af muligheder for interaktion på tværs af sprog og kulturer. Her kan elever og studerende søge og finde, kommunikere og interagere, sådan som det passer til hver enkelt af dem, individuelt og kollaborativt, og her har underviseren også mulighed for at designe opgavetyper, som lægger op til styrkelse af de færdigheder og den viden, som kræves af eleven/den studerende, typisk task-baserede opgaver.

Ud over at den rent intuitive tilgang til nettet i sig selv kan være befordrende for de sproglærende, så er det underviserens opgave at skabe åbne aktivitetstyper, som kan stimulere opøvelsen af de færdigheder, der er målet for undervisningen. Internettet kan dels give adgang til information, som i sprogundervisningen både kan være motivationsskabende, vidensopbyggende og sprogligt stimulerende, dels fungere interaktivt i forbindelse med konferencer og andre synkrone eller asynkrone kommunikationsfunktioner.

\subsection{Nettet som adgang til information og sproglige opgaver}

Internettets enorme informationsmængde gør det muligt for den sproglærende at surfe rundt i en verden, der byder på autentiske oplevelser på målsproget i en naturlig immersionstilgang eller sprogbad ${ }^{3}$, hvor nyt stof tilegnes på fremmedsproget. Spændingen er i sig selv motiverende. Denne tanke findes også hos Piaget som argumenterer for, at undervisningen tilrettelægges efter den lærendes egen aktive eksperimenteren og udforskning. Den sproglærende er nødt til at opdyrke en evne til ud fra nettets fragmenterede information at konstruere viden og opøve reflekterede 
handlefærdigheder, og her bliver opgavedesignet essentielt. Den form for informationssøgning, som man ser anvendt i fremmedsprogsundervisningen på gymnasieniveau, viser sig netop ofte at være en del af en task-baseret opgave i forbindelse med bearbejdning af information til viden og til videre præsentation og formidling.

Mange sproglærere opretter en hjemmeside til deres klasser med linksamlinger opdelt efter de specifikke emner, der arbejdes med. Hjemmesiden fungerer således som en portal mod informationsmængderne, hvor den sproglærende stadig har frihed til at skabe sin individuelle viden. Linksamlingerne behøver ikke begrænse opdagelsesaspektet, men giver et styret startpunkt for elevernes hypertekst-læsning. Ud over den enkelte lærers linksamling findes der flere og flere samlende sider med forskellige typer af opgaver og undervisningsforløb på nettet, som fx "Virtuel fransk" ${ }^{\text {", }}$ der samler en række forskellige fransklæreres materiale, eller fra centralt hold, Undervisningsministeriets "Fagenes infoguide" ${ }^{5}$ som også indeholder relevante linksamlinger for de forskellige fag. Mange af de netbaserede opgaver er klassiske indsætningsøvelser, vendekort og bogstavlege, der arbejder med at opbygge sproglig viden, som skal finde anvendelse i andre typer af opgaver, sådan som det sker i de undervisningsforløb, der er lagt ud.

Alle disse tilgængelige informations- og opgavesider er tydeligst udbygget i sprogundervisningen på grundskole- og gymnasieniveau, og her har især de universitære sproguddannelser et stykke udviklingsarbejde foran sig.

\subsection{Interaktive funktioner}

Internettet kan i høj grad styrke dialog og informationsudveksling, give mulighed for såvel tovejskommunikation som mange-til-mange-kommunikation ${ }^{6}$ med interaktion mellem flere elever på én gang. Samtidig faciliterer det den internationale kommunikation, hvor kultur og samfundskendskab spiller en rolle, hvilket er af stor betydning for fremmedsprogsundervisningen. Der er ingen tvivl om, at fremtidens sprogundervisning i højere og højere grad vil inddrage den autentiske sprogbrugssammenhæng, som kulturmødet udgør, såvel virtuelt som reelt.

Tidsfaktoren spiller en stor rolle for udnyttelsen af mediet i sprogundervisningen. E-mail, konferencer og diskussionslister er asynkrone, mens den kommunikation, der foregår i Chatfora og i MUD- og MOO-verdener ${ }^{7}$ er synkron. Begge dele åbner for en aktiv og konstruktiv læring ved at give de lærende mulighed for at deltage i autentiske, interaktive miljøer i forskellige former for kommunikation, men der er en oplagt forskel på tidsdimensionen i den asynkrone og den synkrone kommunikation. Den asynkrone kommunikation favoriserer refleksion og struktur i kommunikationen, mens den synkrone kommunikation nærmer sig almindelig gruppesamtale, hvor det er muligt at tale på tværs af gruppen. Dette kan her endda finde sted i højere grad, end hvad der normalt vil være tilfældet i tilstedeværelsesbaserede samtaler, idet chatrummet ikke på samme måde registrerer støj, og det ofte endda er muligt at isolere sig, mens man har en deldialog med en enkelt fra gruppen. Eller der kan være en ordstyrer eller moderator der styrer emnevalg eller overvåger, at alle er aktive. 
Internettets kommunikationstjenester åbner for etableringen af en kontekst for autentisk og umiddelbar dialog og dialogkultur, idet internettet til enhver tid stiller et uendeligt stort og varieret udvalg af samtalepartnere til rådighed. Krøjgaard og Grydehøjs spørgeskema-undersøgelse blandt en større gruppe gymnasieelever viser en bevidsthed hos gymnasieeleverne om, at den autentiske kommunikation er befordrende for deres sproglige udvikling. Forfatterne angiver, at 66 \% af de adspurgte har svaret på spørgsmålet, om de kunne tænke sig at få kontakt med brugere af målsproget via internettet: Blandt disse elever udtrykker to ud af tre ønske om en sådan kontakt. Nogle af de realiserede projekter inden for franskundervisningen i gymnasiet viser en meget varieret udnyttelse af nettets muligheder. Krøjgaard og Grydehøj nævner netmedierede projekter med en tekst som udgangspunkt for udveksling af synspunkter mellem klasser, projekter der har centreret sig om kollektiv skrivning af en roman eller en novelle, projekter med diskussion af samfundsrelaterede emner, e-mail eller chat-korrespondance mellem gymnasieelever samt e-mail-korrespondance med franske forfattere og digtere. De danske gymnasielærere, der har eksperimenteret med telekommunikation, er enige om, at inddragelsen af dette element i undervisningen dels er stærkt motiverende for de lærende, og at elevernes ansvarsfølelse og kritiske sans i sprogproduktionen øges. Dette understøttes af en anden gruppe gymnasieelevers evalueringer af et chat-forløb, hvor en positiv holdning er gennemgående. Eleverne fremhæver blandt andet, at den virtuelle chat i sin form formår at tilføre undervisningen et element af virkelighed, der ligger tæt op af en reel fysisk kontakt med brugere af målsproget:

- Man fik nærmest afprøvet sit franske i ”det virkelige liv”.

- Som mulighed synes jeg det er et udmærket alternativ til undervisningen, lidt i stil med udveksling af elever, hvis det er udnyttet rigtigt.

- Da det ikke umiddelbart er muligt at tale med franskmænd (belgiere), synes jeg at chat er et godt alternative.

(cit. Krøjgaard og Grydehøj 2001, s.131)

Ifølge den første evalueringsrapport fra det virtuelle gymnasium (UVM, 2002) oplever fagkonsulenter og lærere, at autentisk kommunikation via e-mail med andre elever, eksperter eller eksterne ressourcepersoner samt offentliggørelse af projekter på hjemmesider er en kraftfuld motivationsfaktor for eleverne. De gør sig særligt umage, når de skal formidle deres faglige kunnen til andre unge. En sproglærer oplever ifølge rapporten, at eleverne stiller større krav om at lære grammatik, så de undgår at lave fejl, og de opsøger selv træningsprogrammer for at udbedre deres svage punkter.

Internettet giver sprogfagene mulighed for en direkte kontakt til de dele af verden, hvor de studerede sprog tales og herved gøre den kommunikative undervisning autentisk, nærværende og motiverende for eleverne. Kommunikationen er ikke nødvendigvis bundet til klasseværelset, og der kan lettere skabes et formål med kommunikationen, når der er en eller flere reelle modtagere af debatindlæg, e-mails eller andre tekster. Denne meningsfulde kontekst kan medvirke til at fokus flyttes væk fra arbejdet med sproget som objekt til at bruge sproget som et medium for kommunikation. Dette ses også i den såkaldte tandem-undervisning, hvor studerende i tandempar på tværs af sprog og kultur 
hjælper hinanden i en autentisk situation omkring eksempelvis løsningen af en fælles projektopgave (Pors 1999).

\section{Undervisning i mundtlig dialog på skrift via computeren}

Mundtlig kommunikationstræning i den traditionelle sprogundervisning består ofte i envejskommunikation i form af forskellige tekstpræsentationer, genfortællinger og handlingsreferater der fungerer som øvelser, hvor eleverne stiller og besvarer en række spørgsmål til en tekst. Den traditionelle klasseundervisning er ofte blevet kritiseret for, at de kommunikative aktiviteter ikke havde noget egentligt formål. Og ligeledes for, at de kommunikative øvelser ikke - på trods af gode intentioner i den kommunikative metode har lagt op til meningsfuld, autentisk kommunikation, hvor både modtager og afsender oplever at have et formål med at kommunikere, og hvori der indgår sprogfunktioner som fx meningsudveksling eller emneskift. Det er en stor udfordring i undervisningen at skabe interaktive kommunikationsformer, der kommer ud over spørgsmål og svar.

Hertil skal opbygges en række kompetencer, herunder sproglig bevidsthed, diskurs- og tekstkompetencer, pragmatiske og interkulturelle kompetencer, hvilket kan gøres igennem åbne opgavetyper, der er designet på baggrund af kommunikative målsituationer. I moderne sprogundervisning skal der arbejdes specifikt med den dialogiske mundtlige sprogfærdighed, som i dag adskilles fra den mundtlige fremstillingsform. Efter det europæiske sprogår (2001) etablerede Europarådet den Falles referenceramme for sprog, hvis grundlæggende princip er, at sprogundervisning primært skal være udgangspunkt for kommunikation. Det er på den baggrund, at et egentligt redskab for sprogundervisning med fokus på sproglæring og selvevaluering, den europæiske sprogportfolio ${ }^{8}$, er blevet til. Her er tale om en klart kommunikativ og aktionel tilgang med tilhørende niveaubeskrivelse (seks niveauer fra A1 til C2) i positive termer: jeg kan ... inden for de fem færdighedsområder lytte-, samtale-, læse-, mundtlig præsentations- og skrivefærdighed. Det er disse niveauer, der har dannet udgangspunkt for beskrivelsen i Fremtidens sprogfag (2003).

\subsection{Chat og sprog}

Chat-sproget deler træk med både skrift og tale. Det er en hurtig skriftlig kommunikationsform, hvor afsender og modtager er til stede samtidig. Der er umiddelbart interaktion som i talen, men man har alligevel mulighed for at planlægge sin taletur og redigere i indlægget, inden man sender det af sted. Chat kan ligesom andre moderne kommunikationsformer som e-mail og SMS indplaceres i kategorien grafisk talesprog. De realiseres grafisk, men ligner dagligdags talesprog mere end skriftsproget der typisk har en længere planlægnings- og produktionstid før det færdige produkt foreligger og som er præget af en større syntaktisk integration.

Jeg vil i det følgende fokusere på især chattens muligheder i et pædagogisk sprogdidaktisk perspektiv. Chat er den mest umiddelbart dialogiske form af de tre nævnte kommunikationsformer, idet der samtidig er flere til stede i kommunikationen, som skiftevis er afsender og modtager. Når man chatter, anvender man en lang række markører, der relaterer sig til interaktionen og til relationen mellem kommunikationsparterne, ligesom i den dagligdags dialog. Det drejer sig om forskellige 
gambitter eller diskursmarkører ${ }^{9}$, som ikke bærer på information om de behandlede emner, men på information om afsender og modtagers indbyrdes relation ( $\mathrm{fx}$ tiltaleformer og grad af direkthed) og om samtaleparternes tilstand og reaktioner på hinandens udsagn. Man kan se, at chat er en spontan og hurtig dialogisk sprogform, der handler mere om proces end om produkt, bl.a. ved at der ofte er tastefejl. De er en fast del af kommunikationen og viser deltagernes engagement i udvekslingen.

\subsection{Samtaletræning på skrift}

På grund af, at skriften optræder som medium for denne samtaletype, kan de lærende her opøve egentlige samtalestrategier i et langsommere tempo, end det er tilfældet i den almindelige mundtlige samtale. Det er specielt for denne kommunikationsform, at der er en næsten synkron interaktiv kommunikation, men at der samtidig er et rum for refleksion og planlægning af næste taletur. På denne måde forberedes den sproglærende på den tilstedeværelsesbaserede kommunikation, hvor netop tidspresset kan virke stressende og præstationsorienteret. Netop denne tidsmæssige forsinkelse, som hører med til chatten, er med til at gøre det computerbaserede træningsrum til et trygt sted, hvor det er muligt at indøve autentisk dialogisk adfærd.

Chatten giver generelt den enkelte langt mere kommunikationstid end den form for klasseundervisning, som er centreret omkring læreren. Dette påskønnes også af eleverne, idet der bliver mere tid til at den enkelte kan udtrykke sig, hvilket virker motiverende. Endvidere virker online-kommunikationen mindre afskrækkende på mere tilbageholdende elevtyper end klasseværelsessituationen. Det kan ligefrem være en fordel, at det sproglige udtryk ikke altid er afhængigt af udtalen af fremmede lyde. Meget tyder på, at den sproglige kompetence styrkes ved den autentiske kommunikation via chatten, selvom den lydlige dimension ikke direkte understøttes af denne. Det er imidlertid tydeligt, at chatten kan anvendes til at opøve de lærendes diskurskompetencer, pragmatiske og interkulturelle kompetencer.

Herudover bevæger internettet sig bort fra udelukkende at være et skriftbaseret medie, hvilket skaber nye perspektiver for chatten. Det er i dag muligt at benytte programmer, der understøtter audio- og audiovisuelle former for chat såsom audiochat, web-telefon og videokonferencer, og det kræver ikke meget mere end den traditionelle chat, ud over højtalere og mikrofon (eller headset) samt webcam. Disse kommunikationsmidler kan anvendes som en opfølgning på arbejdet med den skriftbaserede chat, således at man ikke helt mister de netop skitserede fordele ved denne kommunikationsform.

\subsection{Chat og sproglig kompetence}

I relation til fremmedsprogsundervisningen er målsætningen for den kommunikative metode, at den lærende tilegner sig viden om korrekt og situationstilpasset sprogbrug på målsproget samt udvikler færdighed i praktisk anvendelse af dette sprog.

Hvis elever eller studerende skal lære at deltage i en mere autentisk opbygget samtale på fremmedsproget, er sprogbeskrivelsen nødt til at inkludere dialogopbygning, samtaleregler, replikskifteregulering, sproghandlinger, interaktionsmarkører etc. Der er brug for nye øvelses- og opgavetyper, undervisningsmetoder og arbejdsformer. Og her er 
brug for at komme bort fra den stærkt lærerstyrede undervisning til fordel for en højere grad af deltagercentrering og ansvar for egen læring.

Der foreligger inden for gymnasieskolen gode erfaringer med dialogbaseret sprogundervisning via nettet, ikke mindst som fremlagt i forskellige artikler af Ulla Pedersen og Elisabeth Østergaard (2002, 2003). En af de vigtige pointer for Pedersen og Østergaard er, at computeren giver mulighed for at indøve interaktionen internt mellem de studerende eller mellem de studerende og andre grupper, og for at træne sprogfærdigheden med netop den tidsmæssige margin, som giver mulighed for at reflektere over de sproglige valg. Samtidig bliver det muligt at arbejde med dialogen inden for nogle klare rammer for aktiviteterne og deltagelsen i disse, hvor man kan give tydelige instrukser om anvendelse af de sproglige træk (gambitter, diskursmarkører eller interaktionsmarkører), der kendetegner det dialogiske sprog samt tid til at træne disse. Forfatterne påpeger dog samtidig, at kommunikation med computeren som medie kan opleves som tidskrævende, og at eleverne føler at de indirekte pålægges en større arbejdsbyrde.

Den metode Pedersen og Østergaard anvender, bygger på Lone Ambjørn (2001), der arbejder med et forløb i tre tempi først med forståelsesorienterede øvelser, dernæst med bundne produktive øvelser og endelig med frie produktive øvelser. Eleverne arbejder først med at identificere det ønskede interaktive element, hvad enten det er bestemte diskursmarkører eller emneskift eller andet. Dernæst øvelserne, hele tiden med inddragelse af computeren til at lagre materiale, tekstbanker, lydfiler, videoklip, billeder, samtaler, transskriptioner, glosetræningsprogrammer og ordlister, til at sammenskrive og kategorisere det sproglige materiale, og endelig til at gennemføre samtaler via chat eller konferencer. De to forfattere anbefaler en progression, hvor der først anvendes asynkron kommunikation via en konference, glosetræning og indføring i samtaleteori med simple samtaleøvelser i grupper. Herefter arbejdes med strategisk kompetence ${ }^{10}$, bevidstgørende øvelser og bundne, dernæst frie, samtaleøvelser. På det øverste trin anvendes frie samtaleøvelser med autentiske modtagere, synkrone konferencer med webkamera og chatrum (2003, s. 41).

Når eleverne er utålmodige med computerarbejdet, gælder det ifølge de to forfattere i særlig grad i forbindelse med de forståelsesorienterede øvelser, hvor eleverne træner forståelse og ikke sættes i gang med egentlig kommunikation. Her er eleverne utålmodige efter at komme til at kommunikere. Forfatterne gør opmærksom på, at betydningen af de forståelsesorienterede øvelser står klarere for eleverne senere, når de konstaterer, at de netop i kraft af de forståelsesorienterede øvelser faktisk er i stand til at tale i længere tid og er i stand til at forhindre pinlige pauser i kraft af kommunikationsstrategier og viden om den gode samtale og samtalepartner.

Pedersen og Østergaard opregner (2002) en lang række fordele og ulemper ved disse forskellige former for computerbaseret kommunikation i forhold til tilstedeværelsesbaseret kommunikation. Når vægten skal lægges på fordybelse og refleksion, anbefaler de den asynkrone elektroniske diskussionsform, fordi hver deltager har mulighed for individuel refleksion og formuleringstid. Idéer fra diskussionen er 
elektronisk tilgængelige og kan let redigeres, kategoriseres og lagres til senere brug. Derudover har hver elev hele tiden mulighed for at genlæse allerede indkomne forslag og derved for at lægge mærke til sproglige former, som senere kan indarbejdes i hans/hendes eget sprog. Yderligere fordele er, at eleven kan bidrage med indlæg i sit eget tempo, og det viser sig, at eleverne bruger længere sprogsekvenser og udviser større variation i sproghandlinger end i almindelig samtale. Samtidig fremhæver forfatterne at undersøgelser viser, at deltagernes kulturelle, sociale og statusmæssige forskelle nedtones, således at eleverne i modsætning til den daglige kommunikation fylder nogenlunde lige meget. Dette giver lavere affektive filtre, hvilket betyder, at eleverne er mindre anspændte, nervøse for at begå fejl eller eksponere sig selv, og at de dermed er mere åbne over for læring. Forfatterne fremhæver også, at eleverne har lettere ved at give hinanden konstruktiv kritik i elektroniske diskussioner end uden for disse, samt at de føler sig mere ansvarlige for deltagelse i diskussionen.

Ulla Pedersen og Elisabeth Østergaard fremhæver, at det er væsentligt træk ved deres undervisningspraksis, at der veksles mellem henholdsvis synkron og asynkron kommunikation, fordi kravet om fokus på henholdsvis sprog som proces og sprog som produkt således imødekommes. I forbindelse med synkron kommunikation lægges der vægt på sproget i processen med fokus på fluency, mens der i forbindelse med asynkron kommunikation, hvor eleverne har bedre tid til sproglig refleksion, lægges vægt på sproget som produkt med fokus på korrekthed. Det er i denne forbindelse vigtigt, at eleverne er klar over, hvilket fokus der vælges hvornår, da dette giver dem rammer for at turde give los og kommunikere frit, når dette er målet. Den gemte synkrone chat kan danne udgangspunkt for en fordybet og reflekteret opsamlende asynkron kommunikation eller opsamling, hvor fokus lægges på den tekstlige sammenhæng og sproglige korrekthed. Eleverne bringes på denne måde til at reflektere over eget og andres sproglige output og træner hermed deres monitorering af eget output, hvilket er vigtigt for sprogtilegnelsen og for den fortsatte udvikling af intersproget.

Et af problemerne ved den elektroniske samtale er imidlertid ortografien, idet kravet om skriftlighed giver retstavningen en væsentlig rolle, således at der kræves en større grammatisk kompetence af eleverne, end en traditionel samtale gør. Pedersen og Østergaard (2002) nævner i denne forbindelse, at de nyeste softwarematerialer til sprogundervisningen tager hensyn til dette og er i stand til at gætte betydning til trods for forkert stavemåde. Dette er et vigtigt skridt hen imod en differentiering af fejl, således at der i første omgang fokuseres på kommunikationen (kommunikationsfejl) og senere i forløbet ses nærmere på forskellige form- og strukturfejl, i sammenhæng med en fælles fokuseret opmærksomhed på disse, eller ud fra at eleverne selv har bemærket problemer på dette niveau.

\section{Korpora i undervisningen}

Sprogdatabaser eller korpora er store tekstsamlinger, der er tilgængelige på nettet, eller som man kan købe adgang til. De kan indeholde søgningsmuligheder, være taggede, dvs. indeholde kodninger for sproglig analyse, eller det kan blot være tekstdokumenter. Et elektronisk korpus bruges både til at arbejde med modersmålet og til at lære fremmedsprog, og de kan anvendes på mange måder, både i forskning og i undervisning. 
Learnerkorpora er samlinger af transskriptioner over fremmedsprogselevers sproglige udvikling, ofte i sammenligning eller i direkte interaktion med indfødte. Herudfra kan man opnå en meget velfunderet viden om sprogtilegnelse generelt og om elevernes eller de studerendes sprog og sproglige udvikling (Westin 2005, Granger 1998, 2004), hvor man tidligere har baseret sig på antagelser om eksempelvis betydningen af modersmålets indflydelse på fremmedsprogslæringen. Ud fra learnerkorpora har man således studeret sprogelevers og sprogstuderendes intersprog, og den udvikling, som det undergår i løbet af sprogtilegnelsen, hvilket muliggør en bedre tilrettelæggelse af særligt progressionen i undervisningen, men også en klarere og mere objektiv (ikke baseret på den enkelte undervisers egne erfaringer) hensyntagen til fejltyper og transfer fra modersmålet eller andre fremmedsprog, blandt andet ud fra sammenligninger mellem indfødte og fremmedsprogstalende (native og non-native), studier af særligt hyppigt anvendte ord, ordsekvenser og fejl (cf. Granger 1999, Meunier 2002).

Anvendelse af databaser og netbaserede modersmålskorpora i

fremmedsprogsundervisningen giver et autentisk udgangspunkt for at studere det enkelte sprog i skrift og tale på en måde, hvor de studerende ikke får den sproglige viden præsenteret af læreren, ordbogen eller grammatikken, i en tilrettelagt, abstrakt form. I en sprogundervisning, der tager udgangspunkt i tekstkorpora, skal de sproglærende selv ved hjælp af eksempler formulere regler og se mønstre eller gætte på betydning af ord og vendinger, ud fra det indsamlede eksempelmateriale. Det er ikke længere et instruktivistisk læringssyn der dominerer, idet det er den studerende selv, der kommer i centrum for læreprocessen, og som selvstændigt formulerer hypoteser og konstruerer viden. Denne undervisningsform understreger de studerendes læringsproces og gør det ekstra oplagt at arbejde differentieret.

Der er en række grundlæggende fordele ved at arbejde med databaser i sprogundervisningen. I modsætning til almindelige ordbøger er sproget opdateret og man kan se ord eller udtryk i en oprindelig autentisk sammenhæng. På den måde kan man også se, hvor hyppigt et ord eller et udtryk er og undgå at lære nogle ord eller vendinger som slet ikke anvendes mere. Man kan også vælge at søge inden for en bestemt genre, fx journalistisk sprog eller litterært sprog eller kun at søge inden for talt sprog. En afgørende pædagogisk fordel hænger sammen med evnen til indlæring af viden, man selv har skaffet sig i forhold til viden, der serveres for en: Man husker bedre det, man selv har fundet frem til. Mange sprogelever kender fornemmelsen af at slå det samme ord op i ordbogen igen og igen eller af at læse den samme paragraf i grammatikken mange gange uden at kunne anvende reglen. Når man selv har gættet sig frem til et ords betydning ud fra forskellige sammenhænge, husker man det lettere, ligesom man bedre forstår og husker, hvilken præposition, der normalt skal bruges efter et bestemt verbum eller sammen med et bestemt substantiv, hvis man selv har udledt denne regelmæssighed ud fra konkrete eksempler i et korpus ${ }^{11}$.

Mange studerende er ofte netop dygtige nok til at identificere en mindre heldig formulering i deres eget sprog, men ikke til at finde den grammatisk korrekte løsning eller det mere eller mindre faste udtryk, der ville være naturligt for en modersmålstalende 
i den konkrete sammenhæng (det idiomatisk korrekte udtryk). Her er det oplagt at kunne søge efter bestemte kendte substantiver eller verber og umiddelbart se de sammenhænge de typisk indgår i.

Anvendelsen af elektroniske korpora handler imidlertid ikke kun om at lære at anvende de rigtige udtryk eller at minimere syntaksfejl, men også at nå ud over dette niveau og få de studerende til i højere grand at fokusere på indhold, tekststruktur og genre. Dette sker bl.a. ved at de studerende får mulighed for via nettet at få direkte adgang til mange forskellige typer af autentiske tekster på fremmedsproget. Det ideelle er, at den enkelte sprogstuderende opnår en viden, om hvor forskelligt sproget anvendes i de forskellige genrer og registre, hvilket den korpusbaserede sprogforskning i de sidste årtier har arbejdet kraftigt på at bidrage til (Biber, Dubois, Gadet, Traverso, Ochs, Poos, Swales).

\subsection{Eksempler på korpora på internettet}

Mange tekstsamlinger er direkte tilgængelige på nettet, både store samlinger af skrevne tekster, avisdatabaser og databaser over tekster, der er anvendt i forbindelse med ordbogsarbejde, og samlinger af mundtlige data, der er transskriberet i almindelig ortografi. De findes på mange forskellige sprog i både skrift og tale. Med et korpus kan man undersøge, hvordan ord bruges, hvilke vendinger de typisk indgår i, om der er ord, der næsten ikke bruges mere, og hvilke nye ord der er kommet ind i sproget. Flere netbaserede korpora har indbygget søgefaciliteter, nogle er tagget, nogle er rene tekstbanker, som er lagt på nettet. I det sidste tilfælde har man blot brug for et særligt program til at søge i teksterne, nemlig et konkordansprogram, hvilket netop er automatisk inkluderet i de databaser, der har søgefaciliteter, og hvoraf der findes en række forskellige typer. Jeg vil imidlertid ikke i nærværende fremstilling komme ind på tekniske detaljer om hvilke parsere og konkondansprogrammer, der kan være mest velegnede, men gøre opmærksom på at udvalget af såvel korpora, både skriftlige og mundtlige, og af søgeprogrammer til disse er stadigt stigende og gør det muligt at finde frem til virkeligt anvendeligt materiale for studerende på forskellige niveauer. Flere korpora fungerer som udvidede leksika og har opslags- og søgefunktioner, som kan stimulere den sproglige appetit hos de fleste. Nogle steder kan man således slå op under dagens ord eller under nye ordgrupper og finde lister over dagsaktuelle ord og udtryk, eller man kan søge hvilke ord der hyppigst forekommer sammen, hvilket er nyttigt når man skal lære nye sprog. Det kan være hensigtsmæssigt at vide, hvilke adjektiver, der hyppigt forekommer sammen med et bestemt substantiv og med hvilke betydninger, eller hvilket verbum, der typisk vil befinde sig umiddelbart efter et bestemt substantiv. Flere af disse korpusbaserede databaser indeholder også sætningssegmenteringsprogrammer, der kan analysere sætninger, og man kan finde ordlister over hyppige ord, navne eller de sidste 10 års mest politiske ukorrekte udtryk (se Wortschatz Deutsch Lexikon: "Unwörter") ${ }^{12}$.

\subsection{Betydningen af korpora for vores viden om sprog}

Generelt betyder anvendelsen af korpora i lingvistikken en mulighed for at komme ud over den introspektion, som megen sprogforskning naturligt nok har været præget af. Den mest udbredte praksis vedrørende eksempelmaterialet i grammatikker og også i den teoretisk orienterede sprogforskning har været, at sprogforskerne selv fandt på eller fandt 
frem til de eksempler, som belyste deres teorier om sproget. Dette er principielt ikke noget problem, men den empirisk orienterede korpuslingvistik lægger op til en sprogbeskrivelse der bygger på reelle forekomster, mulighed for kvantitative undersøgelser, frekvensundersøgelser og reelle genrestudier, hvor det kan undersøges hvilke typer af tekster eller medier der anvender bestemte typer af ord, sætningstyper eller udtryk.

Især for vores viden om det talte sprog har udgivelsen af samlinger af mundtligt materiale været et stort spring fremad, fordi det har gjort det muligt at udtale sig om, hvad folk faktisk siger og dermed kunne beskrive den konkrete sprogbrug i forhold til de idealer grammatikkerne opstiller, oftest på baggrund af skriftlige normer og idealer om sproget. Det har gjort talen tilgængelig for udforskning og dermed skabt behov for en udvidelse af sprogbeskrivelsen med ny terminologi til at dække de andre typer af sproglige funktioner vi bruger, når vi taler med andre, og som ikke har nogen berettigelse i skriftsproget. Denne viden og disse termer er netop væsentlige når det gælder undervisning i mundtlig sprogfærdighed, i særdeleshed samtale og dialog, som vi skal se i afsnit 4.

\subsection{Korpusbaseret sprogundervisning og læringsstil}

Selvom der er åbenlyse fordele ved at anvende elektroniske korpora i

sprogundervisningen, så er anvendelsen stadig forholdsvis begrænset, både i Danmark og i udlandet. Denne situation er beskrevet af Aston (2001) og af Caviglia (2005). Aston begrunder dette forhold med manglende eller svag kommunikation mellem forskere og undervisere, men peger også på, at anvendelsen af korpora ikke nødvendigvis giver mulighed for at arbejde med de emner, som såvel forsker som underviser finder mest interessante. Når der arbejdes med frekvens, er det andre grammatiske spørgsmål, der bliver centrale, end når man arbejder med en udtømmende grammatisk beskrivelse af et givent sprog. Arbejdet med korpora og konkordanser i undervisningen tager således klart plads fra de mere klassiske grammatiske emner og regeldannelser, som grammatikkerne har overleveret, men som ikke længere nødvendigvis er særligt produktive eller relevante. Man kan tilføje at anvendelsen af korpora ofte virker unødigt tidskrævende på såvel undervisere som studerende. Netop dette diskuterer Caviglia (2005), hvor han tager udgangspunkt i forskellige resultater med anvendelse af korpora i undervisningen i skriftligt italiensk på universitetsniveau for at konkludere, at de fleste af de studerendes bevidste sproglige problemer kan løses ved denne metode, men at det samtidig er tydeligt, at ikke alle studerende er lige tilfredse med at anvende korpora og konkordanser i skrivearbejdet. Caviglia foreslår således, at der, ud over de korpora der findes, udvikles ad hoc tekstkorpora specifikt til undervisningsbrug på forskellige niveauer, og at mulighederne med arbejdet med korpora som redskab til at skabe sprogbevidsthed gøres tydelige i sprogstudiernes fokus og curriculum, hvilket også omfatter anvendelse af computer, korpora og netadgang til eksamen. Her er der typisk mange steder i dag stadig kun mulighed for at bruge en almindelig en- eller tosproget ordbog eller evt. slet ikke at anvende hjælpemidler og derfor kun at bruge computeren som skrivemaskine. Dette er ikke nogen holdbar situation i moderne sprogundervisning, og det er klart en opgave for universiteternes sprogfag at udvikle eksamensformer, der tester de studerendes anvendelse af internettet, både til arbejdet med egen sprogfærdighed, til lingvistiske 
undersøgelser, til kritisk refleksion over såvel dets didaktiske som dets vidensmæssige potentiale.

Caviglia (2005) rapporterer sin anvendelse i undervisningen af et 6 mio. stort ikketagget ${ }^{13}$ korpus baseret på den ugentligt udsendte udgave af den italienske avis Internazionale. Dette korpus kunne købes (billigt) på CD-ROM. De studerende kunne bruge korpusset som referencetekst til deres hjemmearbejde og derved blive mere selvhjulpne og uafhængige af læreren i det daglige arbejde.

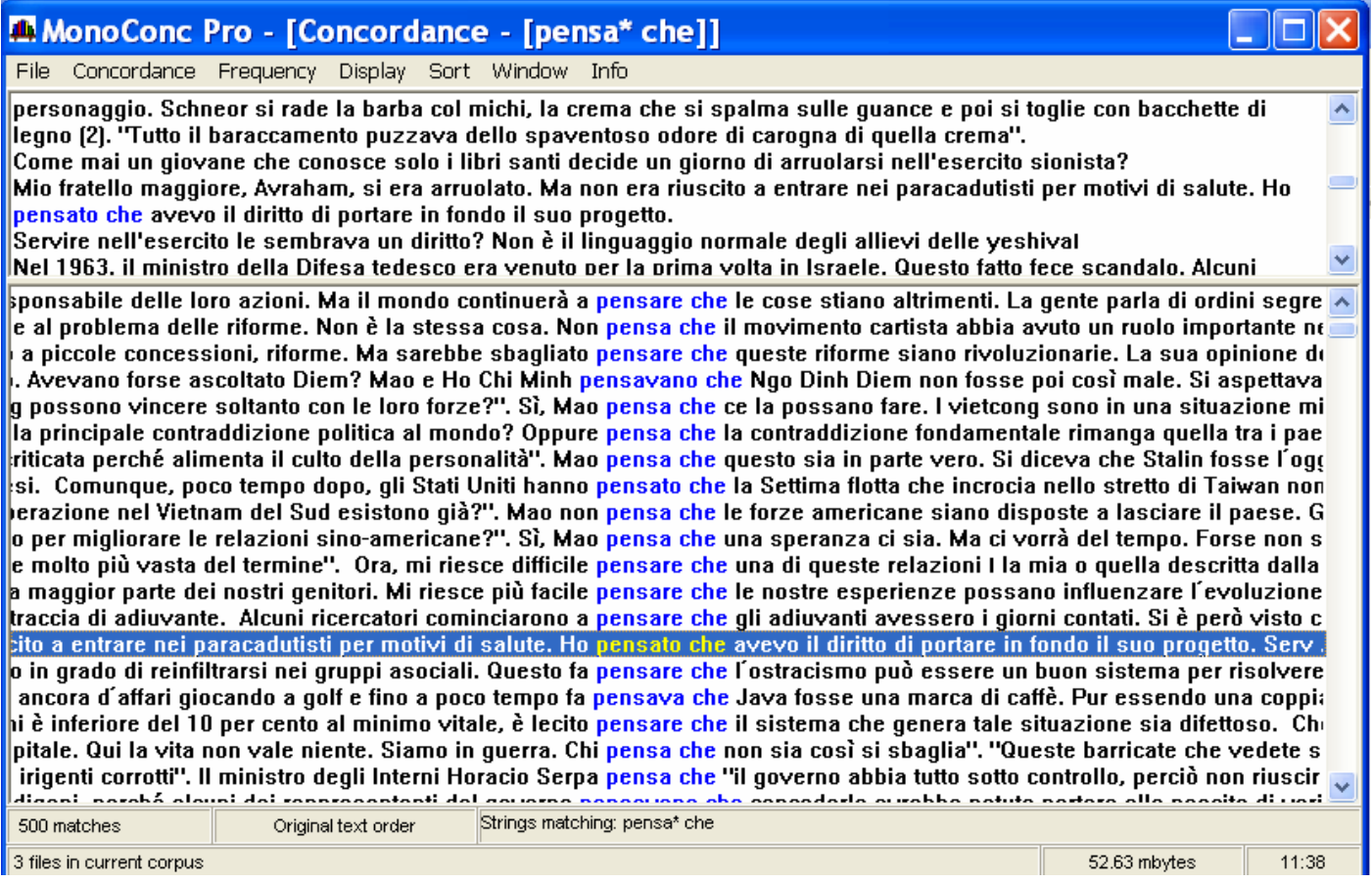

Figur 1. Undersøgelse af, hvorvidt "pensare che” følges af konjunktiv eller ej (Caviglia 2005).

Caviglia (2005) rapporterer, at en lille gruppe studerende fandt anvendelsen af korpus og konkordans meget stimulerende, mens en større gruppe blot lærte teknikken grundlæggende, men ikke anvendte den selvstændigt. Endelig anvendte en tredje mindre gruppe slet ikke muligheden, idet de ifølge Caviglia simpelthen fandt det for besværligt. Den første gruppe bestod typisk af studerende, der allerede kunne en del på fremmedsproget, og som ikke fandt det tekniske svært. Dette underbygges af Stevens (1997), der finder, at studerende der arbejder godt med konkordanser typisk er dem som lærer bedst induktivt ${ }^{14}$, som kan acceptere mindre entydighed, og som er gode til at finde det relevante ud fra en stor datamængde.

Den dygtigste gruppe inden for den konkordansbaserede undervisning viser sig ofte at være de på forhånd dygtige sprogbrugere både på deres modersmål og på fremmedsproget. Det er de lærende, der bevidst kan anvende strategier i deres sprogtilegnelse (cf. Oostdam \& Rijlaardsam, 1995) og som bliver bedre af at anvende et korpus, hvad enten de har en mere systematisk tilgang til sproget eller en mere 
produktionsorienteret tilgang. Alle disse elever kan betegnes som autonome lærende, som er optaget af at finde og genkende mønstre og udlede regler selv. I Bereiters typologi (2002, s. 257-258) vil disse studerende have en læringsorienteret tilgang, hvilket kan karakteriseres ved, at de har vilje til dybdelæring i modsætning til overfladelæring. Bereiter beskriver denne tilgang ved, at målet for den studerende er at udvikle egen viden snarere end blot at løse den udstukne opgave.

Når det gælder grammatiske spørgsmål, føler nogle studerende det bagvendt at skulle lede efter hjælp $\mathrm{i}$ et korpus i stedet for at anvende regler. Caviglia foreslår, at de studerende som ikke bryder sig om en induktiv tilgang, bruger korpusset til at kontrollere deres anvendelse af reglerne. Nogle af disse studerende viser sig at være meget dygtige til at analysere og forklare de resultater, de når frem til i en forespørgsel ved hjælp af konkordansen i korpusset. På denne måde kan Caviglia konkludere, at hvis de studerendes læringsstile respekteres, opfattes konkordansarbejdet som nyttigt ikke blot af entusiaster, men mere generelt af de studerende.

Ikke desto mindre resterer en lille gruppe studerende, som faktisk ikke er i stand til at anvende et korpus og en konkordans til at udlede regelmæssigheder i sproget og anvende de ord og strukturer, de har brug for i deres mundtlige eller skriftlige udtryksfærdighed. Disse studerende overvældes af det dobbelte problem, at de både skal kunne bruge en konkordans (teknisk problem), og at de skal kunne forstå og anvende de fundne eksempler (sprogligt problem). Det er et generelt problem i fremmedsprogsundervisningen, at modersmålsundervisningen ikke anvender en tilgang der sætter fokus på og udvikler sproglig bevidsthed på modersmålet. Anvendelsen af konkordanser i danskundervisningen ville være en god måde at skabe stilistisk og genremæssig bevidsthed hos danske skole- og gymnasieelever, ikke mindst i dag hvor der faktisk eksisterer meget store og veldokumenterede danske korpora (Korpus 2000, Projekt Bysociolingvistik ${ }^{15}$ og Movins korpus $^{16}$ ), som ikke er særligt vanskelige at anvende og helt oplagte til at skabe sproglig bevidsthed hos eleverne, som således ville møde langt bedre rustede op til fremmedsprogsundervisningen.

\subsection{Konkordansanvendelse, snyd eller kvalificering, et perspektiv på eksamen?}

Vil man gerne generalisere anvendelsen af korpora og konkordanser i sin sprogundervisning, så kan det ikke ske uden at det tilsvarende indføres i forbindelse med eksamen. Dette er en konstatering der gælder for næsten alle de arbejdsformer man søger at indføre i universitetsundervisningen (Andersen 2005a). Caviglia rapporterer at fra det øjeblik anvendelsen af korpora og konkordanser blev tilladt til eksamen, kunne næsten samtlige studerende se i hvert fald en potentiel fordel i at lære at anvende disse redskaber og deres engagement blev tydeligt forbedret.

Hvis det er tilladt at medbringe ordbog og grammatik til eksamen, er der ikke mange studerende, som opfatter dette som snyd. Med en ordbog er det muligt at slå ord op og blandt en række synonyme ord og udtryk finde det, der er rigtigt i sammenhængen. Med en grammatik er det nødvendigt selv at finde den rigtige regel og overføre den på det konkrete udsagn. Når det bliver muligt at anvende korpora og konkordanser, bliver det i 
højere grad muligt at vælge mellem mange autentiske udsagn på målsproget og dermed at overføre hele sætninger, uden at de nødvendigvis forekommer forkerte i den konkrete kontekst, som den studerende sidder med. Nogle studerende føler sig utilpasse med at anvende dette redskab, fordi de finder det uselvstændigt og gerne selv vil formulere deres sætninger, mens andre kan være tilbøjelige til at låne hele udsagn, hvilket kan blive så udtalt, at deres egen tekst falder fra hinanden. Caviglia konstaterer, at enkelte af hans studerende netop opnår et sådant resultat, hvilket han finder endnu dårligere, end hvis de ikke havde brugt en konkordans. Han forbinder dette med Bereiters tese om, at elever først og fremmest lærer de minimale færdigheder, som er nødvendige for at klare det, der kræves (Bereiter 2002, s. 274). Hvis det der kræves, primært er syntaktisk korrekthed, så kan dette opnås ved anvendelse af et korpus. Derfor er det vigtigt at formulere helt klare eksamenskrav, hvor man er sig sit sprogsyn bevidst og tager disciplinen alvorligt; skriftlig sprogfærdighed handler ikke blot om syntaktisk korrekthed, men om at kunne konstruere og producere en sammenhængende og velfungerende tekst, hvad enten det drejer sig om en argumenterende, en fremsættende eller en helt tredje teksttype.

\subsection{Hvilket korpus? Hvilket målsprog?}

Når der anvendes et eller flere korpora i undervisningen, bliver dette eller disse autoriteter i forhold til, hvad der rent sprogligt kan regnes for at være korrekt, og herved rykkes der nødvendigvis ved lærerens autoritet. Dette har naturligvis givet anledning til debat (Owen 1996, Widdowson 2000), men ikke til uenighed om, at det er læreren, der beslutter, hvilket sprog, der skal undervises i, og som derfor har det sidste ord i tvivlssituationer, både ud fra sin viden om sprog og sprogtilegnelse og ud fra sin sproglige intuition. Her bør man kunne regne med, at man i såvel grundskole og gymnasium som i de videregående sproguddannelser generelt underviser i korrekt dagligdags standardsprog i skrift og tale. Men også her kan de forskellige korpora hjælpe såvel studerende som underviser til at bevidstgøre sig om, hvad standardsprog er, og hvordan sproget anvendes inden for specifikke genrer, hvilket er væsentligt både i undervisning i sprogfærdighed og i relation til oversættelse mellem sprogene.

\subsection{Særligt designede korpora til undervisning?}

Tribble (1997), Aston (2002) og Caviglia (2005) foreslår, at der opbygges helt specifikke korpora til undervisningsbrug, således at man fx på baggrund af en række større korpora udvælger en undergruppe af tekster, der er tilpasset målsproget. Anvendelsen af et sådant sproglæringskorpus vil klart nærme sig moderne ordbøger, som i høj grad bygger på autentiske aktuelle eksempler fra forskellige tekstsamlinger. Dette er imidlertid ikke det samme som at indbygge et åbent tekstkorpus og et konkordansprogram i en elektronisk ordbog, understreger Caviglia (2005). Han nævner den elektroniske version af Collins COBUILD Advanced Learner's English Dictionary, som direkte linker hvert enkelt lemma med dets forekomster i et korpus på 5.000.000 ord; også Longman Dictionary of Contemporary English CD-ROM viser forekomster i et mindre korpus på 1 mio. ord. Caviglia fremhæver samtidig, at ingen af de to ordbøger giver brugeren mulighed for selv at lave forespørgsler til korpusset eller at opstille resultaterne. Dette gør det umuligt at finde oplysninger, som ordbogsredaktøren ikke har forudset, og især for universitetsstuderende er dette aspekt beklageligt. Derfor vil en kombination af 
elektroniske ordbøger og tekstkorpora uden tvivl fortsat være det optimale for sprogstuderende.

\section{Moderne lærerroller i IT-baseret undervisning}

Når elever og studerende selvstændigt skal anvende internettet, træne dialoger i grupper eller chatte med modersmålstalende i andre lande, kunne man forledes til at tro, at læreren blev overflødig eller i hvert fald mindre central. Det sidste er til dels rigtigt for den konstruktivistiske tilgang til læring, som synes velegnet til den IT-understøttede undervisning. I sprogundervisningen er det oplagt den lærende og dennes færdighedsopbygning og videnskonstruktion, der bliver central. Lærerrollen bliver ikke den direkte styrende, skulptøren, men den vejledende, coachende, bevidstgørende og opmuntrende. Herved forbliver lærerens rolle central og principielt langt mere væsentlig end valget af forskellige IT-systemer og software. Det er læreren, der sikrer, at kommunikationen bliver udbytterig, at der er fokus på det faglige, og at lærermidlerne er tilrettelagt således, at de kan give det ønskede udbytte.

I undervisningseksemplet med skriftlig sprogfærdighed og anvendelse af korpora og konkordanser er det tydeligt, at der er brug for en underviser med en stærk sproglig bevidsthed og en klar formidling af de kompetencemål, som undervisningen lagde op til, og som skulle indgå i bedømmelsen til eksamen, for at mediet ikke blev misbrugt af de studerende, som netop havde ambitioner om at opfylde minimalkravene til eksamen.

Når man anvender internettet til task-baserede opgaver med en kombination af vidt forskellige kompetencekrav kræves både en stærk tilrettelæggelse, for at alle typer af elever og studerende får opgaver, der ikke stiller uoverstigelige krav og leder til nederlag for enkelte og samtidig en indfølende konsulentbistand, som ikke overtager opgaven men stiller netop de spørgsmål, der kan hjælpe eleven eller den studerende videre på egen hånd.

I tilrettelæggelsen af en målrettet samtaletræning kræves det, at underviseren har en bred lingvistisk viden om såvel sætningens opbygning som samtalens grammatik, som den fremstilles i moderne konversations- eller diskursanalyse. Der fordres et indgående kendskab til stilistik og en god sproglig intuition. Når arbejdet tilrettelægges for de studerende, er det vigtigt at kende til sprogtilegnelse, rækkefølgen i tilegnelsen af sproglige størrelser og anvendelsen af gambitter og diskursmarkører i forskellige typer af interaktion for at kunne støtte de studerende i deres tilegnelse af sproglige størrelser, som ikke findes i et ét-til-ét-forhold med en klar reference til konkrete størrelser i verden, men som handler om interaktion mellem mennesker, der tilhører forskellige kulturer.

Tilrettelæggelsen af netbaseret undervisning kræver evne til at forudse såvel tekniske som sproglige og pædagogiske vanskeligheder, og udførelsen kræver et koncentreret og professionelt fagligt og personligt nærvær.

Der findes en række forskellige undersøgelser af IT-integrationen både i grundskolens og gymnasiets generelle undervisning ${ }^{17}$. Der fokuseres i de fleste rapporter på behovet for 
læreruddannelse, herunder gymnasie-IT (det pædagogiske IT-kørekort ${ }^{18}$ ) og mere udstyr, samt på integration af IT i arbejds- og eksamensformer.

Den nuværende regering nævner i sit arbejde med modernisering af prøver, eksamener og karakterer $^{19}$, at den vil fremme, at der anvendes prøveformer, som i højere grad bygger på informationsteknologien som medium, når det er fagligt relevant, og når udbyttet står mål med omkostningerne.

Sprogfagene i gymnasiet er stadig inde i en afsøgende fase over for det nye medie, hvilket de mange forsøg med at integrere IT, som flere af landets gymnasier har deltaget eller deltager i, vidner om, herunder samarbejdsprojekter på tværs af landegrænser, men det er tydeligt, at flere og flere lærere har egen hjemmeside og naturligt anvender internettet til informationssøgning og interkulturel kommunikation. I de nye læreplaner i gymnasiet har anvendelsen af IT en fast paragraf, § $3.3 \mathrm{i}$ alle fag, mens man i de nye studieordninger på universiteternes sprogfag endnu ikke finder IT som en integreret arbejds- og eksamensform, ligesom der ikke generelt er fokus på IT som didaktisk læremiddel i disse uddannelser.

\section{Konklusioner}

IT og internettet kan anvendes på forskellige måder i sprogundervisningen, og selvom vi endnu ikke udnytter mediets pædagogiske og teknologiske potentialer til fulde, er det positivt at så megen fremmedsproglig viden er tilgængelig for eleverne i det globale klasseværelse, både i form af korpora, internetsider og forskellige opgavesamlinger. Al denne viden kræver naturligvis indsigt i de pædagogiske muligheder i anvendelsen af det nye medie. Men alene elevernes motivation for at anvende internettet må inspirere sprogundervisere på alle niveauer.

Dialogen i det traditionelle klasseværelse vil i fremtiden sandsynligvis i mere omfattende grad blive suppleret med kommunikation i virtuelle fora, således at der vil blive tale om tovejskommunikation mellem enkeltpersoner og mange-til-mange kommunikation i konferencer der vil være struktureret efter interesseområder. Arbejdsformerne vil i kraft af dette formentlig udvikle sig i retning af mere projektbaserede og samarbejdsorienterede former.

Der er ingen tvivl om at såvel skoler og gymnasier som universiteter vil opleve udviklingen af en mindre rigid opfattelse af begrebet undervisning, fordi denne kan differentieres i både tid, sted og person. Computeren giver mulighed for både individualiseret og differentieret undervisning og de elektroniske databaser er de moderne læremidler som elever og studerende anvender til informationssøgning og informationsbearbejdning.

Når det gælder den færdighedsbaserede del af sprogundervisningen vil anvendelsen af internettet og andre kommunikationsmidler som vi har set ikke blot styrke de skriftlige kommunikationsfærdigheder, men også de mundtlige. 
Endelig skal det understreges at hvis man ønsker at indføre IT i sprogundervisningen både fordi det faktisk har en effekt på elevernes motivation, kultur- og sprogviden og deres sproglige færdigheder og fordi IT-kompetencen generelt er efterspurgt hos aftagerne af de færdige kandidater, så er det vigtigt at tænke på at indføre IT-baserede eller IT-støttede eksamensformer. Mange lærere udtrykker et klart ønske om at eksamensformerne bliver ændret, så de i stigende grad afspejler den dagligdag som lærere og elever arbejder i. Det kan for eksempel være anvendelse af alle moderne materialer og værktøjer, herunder internettet, enten i forbindelse med længere skriftlige eksamener eller i forbindelse med forberedelse til mundtlig eksamen.

Denne artikel inviterer således til fortsat diskussion med følgende spørgsmål:

- Hvordan kan man styrke lærernes IT-kompetence generelt?

- Hvilke undervisnings- og eksamensformer skal man understøtte for at udvikle IT i sprogundervisningen?

- Hvordan kan IT anvendes udbytterigt i forbindelse med udvikling af sprogfærdighed og sproglig bevidsthed i universitetsuddannelserne?

- Skal IT-didaktik være en del af de sproglige universitetsuddannelser?

\section{Litteratur}

Ambjørn, Lone (2001a): Talt interaktion anskuet i et diskursivt, pragmatisk og strategisk perspektiv.Webpublikation, Research@asb, http://130.226.203.32/fbspretrieve/38/0003049.pdf

Andersen, Hanne Leth, 2005a. Eksamen - valg med konsekvenser, Arbejdspapir fra Center for Undervisningsudvikling, 1. Aarhus Universitet.

Andersen, Hanne Leth, 2005b. ”Sprog som nøgle til europæisk selvforståelse. Om nødvendigheden af nytænkende sprogstudier i Danmark”, Merete Birkelund et al.: Sproglig konstruktion af kulturel identitet, Syddansk Universitetsforlag.

Aston, G. (ed.) 2001. "Learning with corpora: an overview”, G. Aston (ed.): Learning with corpora. Bologna: Cooperativa Libraria Universitaria Editrice; Houston TX: Athelstan,-7-45.

Beck, Steen \& Birgitte Gottlieb, 2002. Elev/student: en teoretisk og empirisk undersøgelse af begrebet studiekompetence, Odense: DIG.

Bereiter, C. (2002). Education and mind in the knowledge age. Mahwah, New Jersey:

Erlbaum.

Bille, Trine, et al., 2005. Danskernes kultur-og fritidsaktiviteter 2004 - med udviklingslinjer tilbage til 1964. AKF forlag.

Caviglia, Francesco (2005). "Students' diverse appreciation of text corpora as writing aids”,T. Caudery (ed.), Proceedings of the Ninth Nordic Conference for English Studies (NAES 2004), Aarhus, Denmark, 27-29 May 2004 http://www.hum.au.dk/engelsk/naes2004/papers.html

Chapelle, Carol A., 2001. Computer Applications in Second Language Acquisition. Longman.

Dysthe, Olga (red), 2003. Dialog, samspil og læring, Århus: Klim.

Granger, Sylviane (ed.), 1998. Learner English on Computer. London \& New York: Addison Wesley Longman. 
Granger Sylviane, 1999. "Use of Tenses by Advanced EFL Learners: Evidence from an Error-tagged Computer Corpus”, Hasselgård H. and Oksefjell S. (eds): Out of Corpora - Studies in Honour of Stig Johansson. Amsterdam \& Atlanta: Rodopi, 191-202.

Granger, Sylviane, 2004. “Computer learner corpus research: current status and future prospects”, Connor U. \& Upton T. (eds): Applied Corpus Linguistics: A Multidimensional Perspective. Amsterdam \& Atlanta: Rodopi, 123-145.

Hedegaard, Marianne, 2001. "Learning through acting within societal traditions: Learning in classrooms”. In M. Hedegaard (ed.), Learning in classrooms: A cultural-historical approach, Aarhus University Press,15-35.

Krøjgaard, Lene Birk \& Anne Grydehøj, 2001. IKT-integration - hvorfor og hvordan? Om læringsprincipper og den nye teknologi i fremmedsprogsundervisningen, Speciale fra Institut for Romansk Filologi, Århus Universitet

Meyer, Bente, 2001. "Den globale dialog - selvkonstruktion og sproglig interaktion i internationale chatrooms”, Birgitte Holm Sørensen (red): Chat - leg, identitet, socialitet og lering, Gads forlag.

Negretti, Raffaella, 1999. "Web-based Activities and SLA: A Conversation Analysis Research Approach”. Language Learning \& Technology, Vol. 3, no. 1, July 1999, pp. 75-87. Online: http://llt.msu.edu/vol3num1/negretti/index.html [10.11.00].

Pedersen, Ulla \& Elisabeth Østergaard, 2002. it og mundtlighed, semesteropgave på Masteruddannelsen i it, sprog og læring.

Pedersen, Ulla \& Elisabeth Østergaard, 2003. ”Erfaringer med ”den naturlige samtale” et forsøg”, Fransk Nyt nr. 238, 36-42.

Meunier F., 2002. "The role of learner and native corpora in grammar teaching”, Granger S., Hung J. and Petch-Tyson S. (eds): Computer Learner Corpora, Second Language Acquisition and Foreign Language Teaching. Language Learning and Language Teaching 6. Amsterdam \& Philadelphia: Benjamins, 119-142.

Nunan, David, 1999. ”Second Language Teaching and Learning”, Heinle \& Heinle Publishers.

Pors, Harald, 1999. "Projektet international tandem network”, Sprogforum 13, 12-16.

Svendsen Pederen, Michael, 2001. "Task force“, Sprogforum nr. 20 (netudgave: http://inet.dpb.dpu.dk/infodok/sprogforum/spr_nr20.html).

Tornberg, Ulrika, 2001. Sprogdidaktik, L\&R Uddannelse.

Undervisningsministeriet, 2002: Fag, pæedagogik og it i det almene gymnasium - status og perspektiver, 1. faglige rapport, Det Virtuelle Gymnasium: http://pub.uvm.dk/2002/virtuelgym1/

Vygotsky, L.S., 1978. Mind and society: The development of higher mental processes. Cambridge, MA: Harvard University Press.

Warschauer, Marc, 1997. "Computer-mediated collaborative learning: theory and practice”, rev. version, Modern Language Journal 81/3.

Westin, Eva, 2005. "Cultural and Historical Narrative in Native and Non-native Speaker Language”, Andersen, Hanne Leth et al.: Culture in Language Learning, Aarhus Universitetsforlag.

Wichmann A., et al. (eds.) 1997. Teaching and Language Corpora, London: Longman. Willis, Jane, 1996. A Framework for Task-Based Learning. Longman. 
${ }^{1}$ Ofte anvender sprogundervisere begrebet $i k t$ for at fremhæve det dobbelte potentiale i den nye teknologi: denne betegnelse ekspliciterer kommunikationsaspektet som er af signifikant betydning for sprogundervisningen. Samtidig er det blevet mere og mere almindeligt at gå ud fra at dette aspekt er en uadskillelig del af informationsteknologien. Det skal samtidig præciseres at nærværende kapitel anvender betegnelserne informationsteknologi og digitale medier parallelt.

2 Begrebet intersprog introduceres af Larry Selinker i 1972 i en artikel "Interlanguage” i International Review of Applied Linguistics, nr 10, hæfte 2, ss. 209-231, som en videreudvikling af Pit Corders "The significance of learners' errors” (1967) i International Review of Applied Linguistics nr. 5, hæfte 2-3, s 161169.

${ }^{3}$ Immersion eller sprogbad er en almindeligt anerkendt tilgang til fremmedsprogsundervisning især i toeller flersprogede lande. Her foregår undervisningen i visse eller alle fag på fremmed- eller andetsproget. Nogle steder er det børnehaven der er forum for immersionsundervisningen. Ideen bag denne metode er at børnene oplever deres dagligdag i børnehaven eller deres faglige arbejde i skolen udelukkende på det nye sprog og derved tilegner sig sproget uden fokus på den sproglige form.

${ }^{4}$ http://fransk.acnord.dk/

${ }^{5}$ http://www.infoguide.dk/fagene/oversigt/subject020100.html

${ }^{6}$ Begrebet many-to-many communication stammer fra Warschauer 1997.

${ }^{7}$ MUDs og MOOs er virtuelle miljøer, der kan anvendes af flere brugere samtidig. Et eksempel på en MOO er MOOFrançais (http://www.umsl.edu/ moosproj/moofrancais.html), der bygger på et virtuelt Paris, hvor spilleren/learneren kan bevæge sig rundt i gader, museer etc., læse og skrive i ”le MOOnde”, chatte med de andre (synkront eller asynkront), lave objekter og placere dem i spillet.

${ }^{8} \mathrm{http}: / /$ culture2.coe.int/portfolio/inc.asp?L=E\&M=\$t/208-1-0-1/main_pages/welcome.html

${ }^{9}$ Gambitter eller diskursmarkører er diskursive størrelser der anvendes i samtaler med forskellige interaktive funktioner, som fx at give feedback, at markere emneskift eller at holde samtalen i gang. De bliver nogle gange kaldt fyldord, hvilket må ses på baggrund af en sprogbeskrivelse der traditionelt har taget udgangspunkt i skriften.

${ }^{10}$ Strategisk kompetence handler om sprogbrugerens mulighed for at anvende en række sproglige og ikkesproglige kommunikationsstrategier når han eller hun mangler et ord eller udtryk hvad enten det er på modersmålet eller på fremmedsproget. Det kan dreje sig om omskrivninger, indlån fra andre sprog, direkte oversættelse fra andre sprog, gestik, mimik osv. Denne kompetence er ikke mindst en væsentlig del af den kommunikative kompetence når man er ved at tilegne sig et fremmedsprog.

${ }^{11}$ Den induktive tilgang til sproglig læring regnes således normalt blandt sprogtilegnelsesforskere for den mest udbytterige i forhold til at kunne anvende sproglig viden til sprogproduktion (se fx Tornberg 2001) Ligeledes antages det at de fleste husker ord, vendinger og strukturer bedst i de omgivelser de er blevet lært. Således går man ud fra at sprog der er tilegnet i en kommunikativ sammenhæng med en specifik kontekst, bedre kan aktiveres i en ny kommunikativ sammenhæng, end ord, vendinger og strukturer der er tilegnet i forbindelse med løsrevne grammatiske øvelser, såkaldte strukturøvelser (se fx Tornberg 2001)

12 Korpus 2000 + korpus 90 (http://korpus.dsl.dk/korpus2000/indgang.php)

Et frit tilgængeligt digitalt opslagsværk over det nyeste danske sprog, på baggrund af en meget stor tekstsamling fra de seneste 10 år. Udarbejdet af Det danske Sprog- og Litteraturselskab (DLS), indeholdende langt over 50 millioner ord. Korpus 2000 består af 28 millioner ord fra ca. 110.000 forskellige tekster skrevet i perioden 1998-2002. I forbindelse med indsamlingen af tekster er ca. 750 forlag, aviser, blade, skoler, foreninger og privatpersoner blevet kontaktet. På hjemmesiden kan man se mange undersøgelser over nye ord, engelske ord, hyppige ord.

The British National Corpus, BNC (http://sara.natcorp.ox.ac.uk/)

Denne elektroniske tekstsamling rummer 100 millioner ord fra bade skriftlige og mundtlige meget forskelligartede teksttyper. Målet er at repræsentere ‘Current British English’. Dette korpus er udarbejdet på Oxford Universitet.

Elicop, Leuven (http://bach.arts.kuleuven.be/elicop/)

Denne database indeholder nedskrevne samtaler fra seks forskellige fransk talesprogskorpora, hvoraf de tre indeholder data fra samtaler med belgiere der er ved at lære fransk. Man kan vælge at søge i disse korpora samlet eller hver for sig. 
LIP, Lessico di frequenza dell'italiano parlato (http://languageserver.uni-graz.at/badip/badip/25_text.php). Et italiensk talesprogskorpus.

Diccionario de la langua española (http://www.rae.es)

Det spanske akademis ordbog med adgang til databaser. I 'El Banco de datos del español' findes mere end 400 millioner opslag, både moderne spansk (synkron datbase: el CREA) og spansk i ældre tekster (diakron database: el CORDE). Her er også adgang til hele den spanske verbalbøjning.

Wortschatz Deutsch Lexikon (http://www.wortschatz.uni-leipzig.de/)

Bag denne enorme databank ligger 35 mio. sætninger med 500 mio. ord. De nyeste eksempler er fra 2003, og man kan slå mere end 9 mio. forskellige ord og ordgrupper op (ud over tysk fx også på engelsk, fransk og islandsk), finde definitioner og eksempler fra den store database som også indeholder en tysk-engelsk ordbogsfunktion.

${ }^{13}$ Uden sproglige annoteringer der angiver det enkelte ords grammatiske funktion, som man kan søge på.

${ }^{14}$ I sprogundervisning skelnes mellem en induktiv tilgang hvor den sproglærende ud fra en række eksempler udleder det underliggende sprogsystem eller den grammatiske regel, og en deduktiv tilgang hvor den sproglærende efter at have fået forklaret og eksemplificeret reglerne, forventes at kunne anvende disse til at konstruere sætninger på målsproget.

${ }^{15}$ www.cphling.dk $>$ projekter $>$ bysoc

${ }^{16}$ http://www.humaniora.sdu.dk/interaction/Datakorpus/Datacorpora.htm og http://talkbank.org/media/Conversation/MOVIN/

${ }^{17}$ Fx Informationsteknologi i det danske skolesystem (http://www.uvm.dk/gammel/oko/it_dk.htm), eller Informationsteknologi og uddannelse (http://www.uvm.dk/gammel/3udg.htm)

${ }^{18} \mathrm{http}: / /$ www.gymnasie-it.dk/

${ }^{19}$ http://pub.uvm.dk/2004/eksamener/ 